

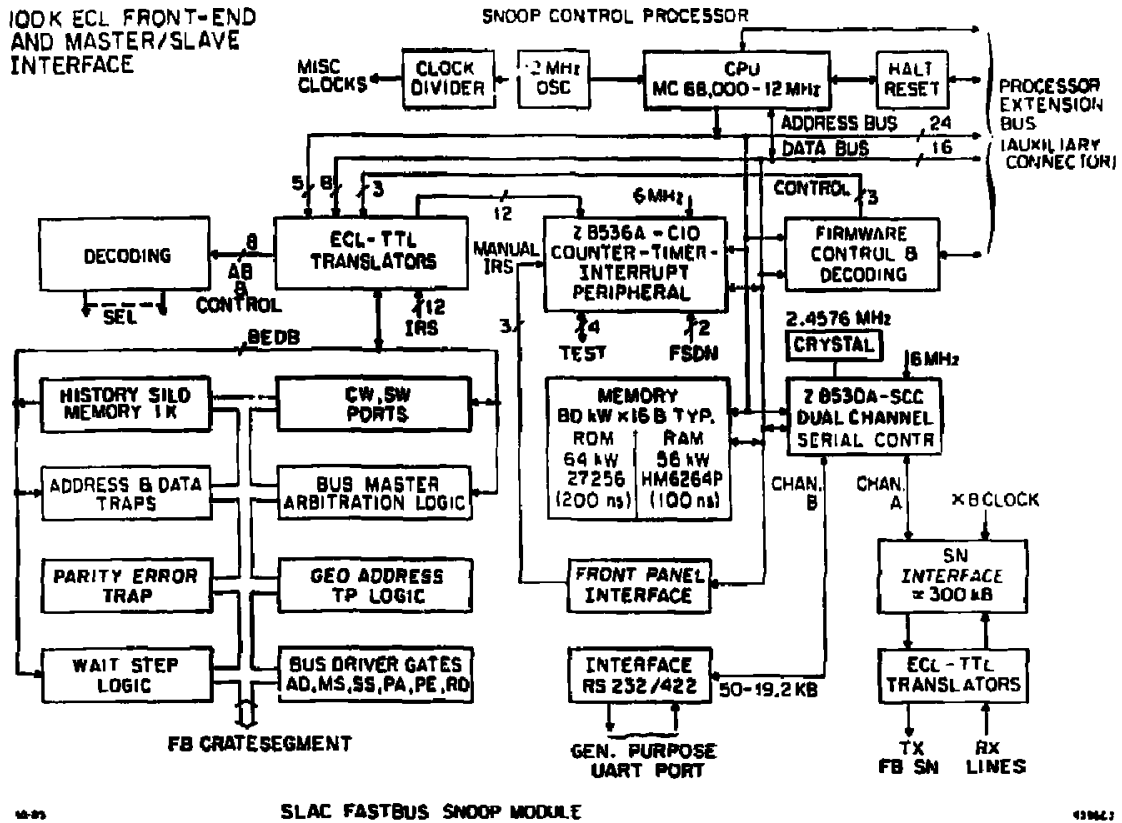

Fis, 2. A block diagram of the Snoop Modula.

The Snoop Module hes served as its own development systean. Once the proceseor, memory and terminal $1 / 0$ were working, ROM contnining a wall Forth nuclews was inatalled. At ditional fenture were teoled and added imerementally, finot by keybonrd entry, next by downlosding from a mert cerminal' diskette drive, and findly by incorporation into the ROM. The amart terminal currently wed is an IBM PC.

The ROM containg a rimple but comprehenslve vace interfees, which allowe complate cobtral of the Snoop by means of - rimple ASCII termind. Menus are avalibble to help the inexporienced uer, and the full Forth programming capability is available as well.

Uning a PC. (or other compuler) Inotead of a dmple terminal odd dink storage capability, muking it poublble to creste a thofed collection of useful dingrastic routines which support troubleshoating work an particular modules, and to dhare such routines with athers. The PC alo add hardeopy pinting capabiinty to the Snoap, and even leat-dita ntorege.

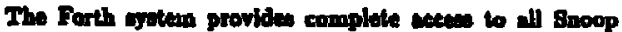
hardwure fentures for thons who need $i t$, whila presenting a vimple and elean model which hidm the dirty detalls from the normal uer. For example,

MAX? AsU-WT

caunes WT to be cenerated by the Gnoep when $\Lambda 8$ goed $\mathrm{V}_{\mathrm{p}}$, and

NO A8U.WT curn. that fenture ofi.
\#3FF. AT-IGNORE \#123800. АT-MATCH MAKE WT-ON-TRAP A-TRAP-MODE

SNST.

60 BILO.

3 B sLLO.

sets up the comperator masking bits to ignore the low-order 10 AD bits, exts the $\mathbf{A D}$ value to be mutched at hexidecimel 123800 , then enables WT Eantention whenever the match oceus during an addreas cycle.

displays the castent 8Noop STtur in text form.

dinplaye tbe 5 FASTBUS cycles last recorded in the eilo memory, and

displays the 3 cycles before those.

In sddition to thene simple interfaces to the Snoop Module's logic-analyzer capabillitem, there are intertaces which allow use of the Snowp a - FABTBUS mater, wo that it can exercise other FASTBUS devicen, or perform simple dnta-collection and analyb ehore. The snoop cets a a RASTYUS alave wing microprocever sinulution with hardware help for (geographic) addrese recognition. The oleve jeginters can alio be aecened by the wor, oo that (for examplo) another manter could be set up to read or write dute to the Gnoop "ulave" for testine purposes.

The FASTBUS Master interfuce wass command names compatible with the proposed FASTBUS Stendard Subroutines, Only - cubset of those funetions will be provided in ROM, but the user has bullding-block routines available for sonerating any additional functions he might wish to have for a particular application. 


\section{MULTLSWOOP NETWORKS}

The Bnoop Module is aloo Inlended for uac in large multiecgment syotems: for diencaing intereannect problems; for aft Int as is remolaly-eontrolled manter to collect dats about, or to stimulate, - broken ugntem; for collocting anmples of eegonent activity without dlaturbing \& running oystem; and for gathering corrolaled informullon from intermittently-connecled segmentu.

Thene function require sothod of control]ing and commu. nicating with muldiple Snoppe in i coordinated way, oomething more eficetive thep exparate terminain connected to oseh Snoop. The FASTBUS Diegnoetic Serial Network we envbioned for this purpoe, and an experimental venton la being implemented in the Bnoop hurdware. The FASTBUs apecifieation ha not do-

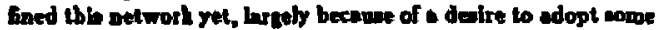
industry standard rather than wing our own unique (and thus expenalve) deston. Protatype work on the aetwork has been carried out unins * Mnnehenter-coded low-peed Ethernet-like echeme, while walting for industry to come up with the right anwer lor FASTBUS.

We are now canverting to the AppleTalk setwork' wed by Apple Corporation for its Macintonh computen and Laserwriter printer. The AppleTalk network unes even leas board space than oss prolotype network, and a subset of the original hurdware, wo we can implement it by simply removing components and inaerting jumpers. AppleTalk une the FMO modulation capabilities of the 2ilog 8530 Serial Commonications Controller, and a Carrier Sene Multiple Aceeso / Collision Avoidance scheme (CSMA/CA) instead of our prototype Manchenter modulation with Carrier Senes Multiplo Aecens/Colition Detection (CSMA/CD) seheme.

We are, of comse, concerned about the future of the AppleTalk getwork in the fuce of competition from higher performance IEEF-Scandard network auch an the Ethernet (IEES 802.3), Token Bus (IEGE 802.4) and Token Ring (IEEE 802.5). We would in priaciple prefer to we one of those standerds, but ecveral obstacle bave made that impractical up to the present time. Finat, rellable ailicon cupport for theos atandards, with adequate denaity to meet our board apace limitations, is jut now tecoming avalibble. Unfortunately, the chip sets ure generally not denighed in 2 way which permits wire-OR connection of multipte noder on the FASTBUS backplane (en absolutely maentia) requitrament for any eventual Diagnatic Network ulendard), and the more eompact inplementatlona are rather procesor-apeific.

In oddition, the high data rales are a problem in two ways: the demando on the procesoor may be so great es to requite s eoproceseor to hundle the lasd of the network, cooting additlonal bowed epece; end, high dula rates place thringent requiremente on eable length ond type which art seriously inconvenient is typical FASTBUS enviroament.

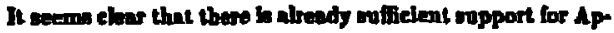
pleTalt that it will be around for nome time, and therefore that it has aignificant edvantages compared to using our own unique deaign. In perticnlar, catomays which conneet AppleTalt with Ethernat are becoming svallable commereially, and this path is probably the aimplest and chooped way wo llat the Snoops with the DEC VAXes and ather computers commonly used in dnte acquisition aystems today.

$A$ wottware effort i currently beginning SLAC to implement the AppleTalt network on the Snoop, uoing Macintooh computorn a development tools. Pratocols appropriste to the Snoop'n functions remain to be underetood, velected and implemented. We intend to include the necessary hookn in the Snoop ROM coltware so that \& Snoop con be activated by either a termind or A PC connecled to lis front panel, or by the FASTBUS Dingnuatic Network connection on the beckplane.

The CDF group at the Ferml Nationsl Accelerator Isboratory han debraged and roed two Snoop Module under control of a propram rumaing on a VAX, wime the front-panel terminal connection to the Snoop."

\section{b. CONCLUSION}

Besic functional teating of the snoop Module protolype in at most completed. The module performs rery relimbly. Additional teating in more comples: and higher-apeed FASTBUS environments afll remains to be done, tachudirs wetual field testing by uners.

During the next weveral monthin, minor hardware correction and completion of ti.e documentation package are planned. A module production run is acheduled during the next 6 montha. It is hoped that this pilot production will be parformed un. der a commereial contract. SLAC is plunning to wake sample quantitie from this produetion run ovallable to the FASTBUS enmmunity. The coot for leated Gnoop Modules with software on-board in expected to be U.S. \$ GK to 8K.

With the fint large multiregment FastBus cyntems now being asembled, we hope that this Snoop Module will become - valuable tool for disegnosing and oolring FASTBUS byotem problems.

\section{ACKNOWLEDGEMENT}

We are grateful to R. S. Lamen for his aupport throughout this project; to Ed Austin for his work on the PC layout; to V. I lanl for his work on the drawings; to Ered Behing for his asiswace in the hardware chectout, coordination support, engineering support, wirelist ereation and arintenance; and to Sergio Zimmermann of FNAl for his colluboration and assistance in the hardware teating.

\section{REFERENCES}

1. H. V. Wals and D. B. Guturnan, status of the SLAC Bnoop Diagnoetic Module for FASTBUS, IDEE TransecHong on Nucl. Sci. NSm30, No. 4, 2276 (1983).

2. "Inaide AppleTulk", Apple Computer, Inc., 20525 Mariani Avehue, Cupertino, CA otors.

3. B. Zimmertmann, Fermi National Accelerator Laboratory, “A FASTBUS Logic Analyzer Baoed on SLAC Snoop Diagnotic Modules", pupar presented at this conference.

\section{DISCLAMMER}

Thb report was propered as an acoosut of wart upouscred by an ageney of the United Stales Goveramene. Netither the United Stated Govemment nar any agengy thereof, nor any of their employees, mukes any warrenty, express or implied, or assumes any legal liabillty or responsibility for the aceuracy, completenea, or usefulness of any information, apparatua, product, or

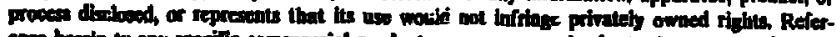

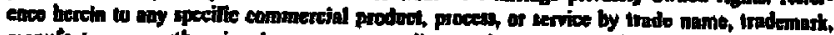

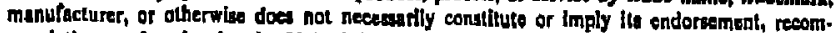
mendation, or favoring by the Uniled States Government or any agency thereof, The views

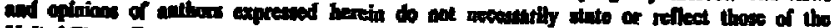
Uwited Sintes Covernment or any apeacy thenof. 